\title{
Acid and low temperature treatments on Salmonella Enteritidis inoculated in pork and its subsequent survival in simulated gastric fluid
}

\author{
Ácido e baixas temperaturas sobre Salmonella Enteritidis inoculada em \\ carne suína e sua sobrevivência subsequente ao fluido gástrico simulado
}

\author{
Simone Quintão Silva ${ }^{\mathrm{I}}$ Miriam Teresinha dos Santos ${ }^{\mathrm{II}}$ \\ Simone Albino Paes ${ }^{\text {II }}$ Maria Cristina Dantas VanettiI
}

ABSTRACT

The objective of this study was to evaluate the acid resistance of Salmonella enterica serovar Enteritidis (S. Enteritidis) in stored pork and in simulated gastric fluid (SGF). A culture of S. Enteritidis was subjected to acid treatment prior to inoculation into pork, stored under refrigeration at frozen temperatures and exposed to SGF. The S. Enteritidis CCS3 and ATCC 13076 strains previously subjected to acid treatment (at pH 4.0-5.0) were inoculated in pork and stored at $4^{\circ} \mathrm{C}$ and $-18^{\circ} \mathrm{C}$. Storage at $4{ }^{\circ} \mathrm{C}$ did not affect the populations of both $\boldsymbol{S}$. Enteritidis strains. After 84 days at $-18^{\circ} \mathrm{C}$, the mean population of both CCS3 and ATCC strains were reduced by 0.8 and $1.5 \log$ cycles, respectively. Prior acid treatment did not enhance the survival of both strains at low temperatures. After acid treatment and low temperature storage, S. Enteritidis ATCC 13076 lost culturability after being exposed to $S G F$ for 10 minutes. In contrast, $\boldsymbol{S}$. Enteritidis CCS3 was tolerant until three hours of SGF exposure. S. Enteritidis CCS3 submitted to $\mathrm{pH} 4.0$ was more tolerant to SGF exposure than when submitted to $\mathrm{pH}$ 4.5, 5.0 and without acid treatment. Therefore, this study indicates that exposure to an acidic and cold environment during processing enhanced the ability of $\boldsymbol{S}$. Enteritidis to survive in the gastric environment of the human stomach, possibly increasing the risk of a Salmonella infection after consumption of pork.

Key words: acid resistance, $S G F$, freezing survival, storage survival, cross-resistance.

\section{RESUMO}

$O$ objetivo deste estudo foi avaliar a resistência ao ácido de Salmonella enterica serovar Enteritidis (S. Enteritidis) previamente submetidas a tratamento ácido e inoculadas em carne suína armazenada em temperaturas de refrigeração e congelamento ao fluido gástrico simulado (FGS). As linhagens de $\boldsymbol{S}$. Enteritidis CCS3 and ATCC 13076 previamente submetidas a tratamento ácido variando de $\mathrm{pH} 4.0$ a 5.0 foram inoculadas em carne de

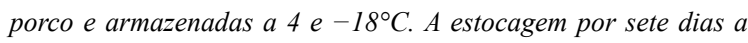
$4^{\circ} \mathrm{C}$ não afetou as populações das duas linhagens de $\boldsymbol{S}$. Enteritidis. Após 84 dias a $-18^{\circ} \mathrm{C}$, as reduções médias das populações das linhagens foram de 0,8 e 1,5 ciclos logaritmicos, respectivamente. $O$ tratamento ácido prévio não aumentou a sobrevivência das duas culturas sob baixas temperaturas. Após tratamento ácido e estocagem em temperaturas baixas, S. Enteritidis ATCC 13076 perdeu a culturabilidade após 10 minutos de desafio ao FGS. Contrariamente, S. Enteritidis CCS3 mostrou-se tolerante à exposição por três horas ao FGS. S. Enteritidis CCS3 submetidas a tratamento ácido prévio em pH 4,0 mostraram-se mais tolerantes à exposição por 180 minutos ao FGS que células submetidas aos tratamentos ácidos em $\mathrm{pH}$ 4,5 e 5,0 e células sem tratamento. Portanto, este estudo indica que $\boldsymbol{S}$. Enteritidis submetida a um ambiente ácido e frio durante o processamento pode melhorar a sua capacidade de sobreviver à barreira gástrica em humanos, possivelmente, aumentando o risco de surto por Salmonella após consumo de carne de porco.

Palavras-chave: resistência a ácido, FGS, sobrevivência ao congelamento, sobrevivência à estocagem, resistência-cruzada

\section{INTRODUCTION}

Salmonella enterica is a pathogen that infects both animals and humans, causing gastroenteritis or systemic infections. To colonize the host, $\boldsymbol{S}$. enterica must overcome the acidity of the stomach, the microbial flora of the gut, and the intestinal barrier in the host (ÁLVAREZ-ORDÓÑEZ et al., 2012). This study evaluated $\boldsymbol{S}$. enterica serovar Enteritidis under various stress conditions, as it is the

\footnotetext{
'Departamento de Microbiologia, Universidade Estadual Paulista (UNESP), Campus de São José do Rio Preto, 15054-000, São José do Rio Preto, SP, Brasil. E-mail: simonequintaosilva@gmail.com. Corresponding author.

IUniversidade Federal de Viçosa (UFV), Viçosa, MG, Brasil.
} 
most prevalent serovar among the brazilian human population (ROWLANDS et al., 2014). Although the main source of Salmonella are eggs and egg products (GANTOIS et al., 2009), other foods such as raw milk, beef and pork was associated to $\boldsymbol{S}$. enterica infection outbreaks (ROWLANDS et al., 2014; CDC, 2015).

Several reports documented the presence of $\boldsymbol{S}$. Enteritidis in swine abattoirs in Brazil (BESSA et al., 2004; KICH et al., 2011). Strategies used in abattoirs to prevent $\boldsymbol{S}$. enterica growth include lower storage temperatures and surface decontamination using acids (SUN et al., 2003; PIPEK et al., 2006). Although these strategies create environments of moderate stress, $\boldsymbol{S}$. enterica is capable of adapting to these adverse conditions, not only in natural environments in animal or human hosts, but also in commercial ones such as abattoirs and food industries (WINFIELD \& GROISMAN, 2003; ÁLVAREZORDÓÑEZ et al., 2012).

However, stress factors encountered during processing and storage of food as well as during passage through host physiological barriers (For e.g. gastric fluid) had a significant effect on the survival of $\boldsymbol{S}$. enterica. The physiological $\mathrm{pH}$ of human fluid gastric can range from 1.5 to 3.5 (MARIEB \& HOEHN, 2010). Studies reported that S. enterica is resistant to acid and low temperatures conditions (MÜLLER et al., 2012). Bacteria adapted to mild acid stress survived in similar or different stress conditions due to a cross protection effect (SPECTOR \& KENYON, 2012). Moderate acidic conditions could trigger resistance to gastric fluid in S. enterica, increasing the risk and severity of illness (YUK \& SCHNEIDER, 2006).

There was significant increase in the prevalence of $\boldsymbol{S}$. Enteritidis and incidence of human salmonellosis in recent years. Moreover, acid tolerance is an important virulence factor related to survival of foodborne pathogens at low $\mathrm{pH}$ conditions of the gastric barrier. Studying the stress factors, therefore contributes to the resistance development in $\boldsymbol{S}$. Enteritidis, which became increasingly relevant. The objective of this study was to evaluate the effect of $\mathrm{pH}$ and low storage temperatures on $\boldsymbol{S}$. Enteritidis and its subsequent growth in simulated gastric fluid (SGF).

\section{MATERIALS AND METHODS}

\section{Bacterial strains}

Salmonella enterica serovar Enteritidis strains (ATCC 13076 and CCS3) were used in this study. The CCS3 strain was isolated from a swine carcass in a abattoir in Brazil (LIMA et al., 2004). Acid treatment

$S$. Enteritidis strains were grown in Trypticase Soy Broth (TSB; pH 7.2) at $37^{\circ} \mathrm{C}$ for $12 \mathrm{~h}$. For acid treatment, the cells were suspended at a concentration of $10^{8} \mathrm{CFU} \mathrm{mL} \mathrm{mL}^{-1}$ in TSB, adjusted to different $\mathrm{pH}$ (4.0, 4.5 , and 5.0) with hydrochloric acid $\left(5 \mathrm{~mol} \mathrm{~L}^{-1}\right)$, for $1 \mathrm{~h}$ at $37^{\circ} \mathrm{C}$. After the acid treatment, the non-challenged and acid-challenged cells were centrifuged at $1275 \mathrm{x} g$ for $10 \mathrm{~min}$ at $4^{\circ} \mathrm{C}$. Pellets were resuspended in $0.85 \%$ sterile saline solution at a concentration of $10^{8} \mathrm{CFU} \mathrm{mL} \mathrm{mL}^{-1}$ for subsequent experiments.

\section{Inoculation in cold and frozen pork}

Pieces of pork loin (Longissimus dorsi) were first exposed to ultraviolet radiation for $30 \mathrm{~min}$ for surface decontamination. Pork samples $(10 \mathrm{~g}$ each) were removed aseptically from the inside of the muscle and placed in sterile plastic bags. Aliquots of $1 \mathrm{~mL}$ of non-challenged and acid-challenged $\boldsymbol{S}$. Enteritidis ATCC 13076 and CCS3 (as described above) were transferred to the pork samples and spread uniformly. Pork samples were stored at $4 \pm 1^{\circ} \mathrm{C}$ for up to 7 days and at $-18 \pm 1^{\circ} \mathrm{C}$ for up to 84 days. Non-inoculated pork samples were used as controls. All assays performed simultaneously, used the same equipment. The temperature of the equipment was monitored during the experiment.

Viable counts

The viable counts were determined by the drop plate method (MORTON, 2001). First, $90 \mathrm{~mL}$ of $0.85 \%$ saline solution were added to a portion of pork loin and homogenized in a stomacher (Laboratory Blender Stomacher 400, Seward) for $2 \mathrm{~min}$. Aliquots of the homogenate were serially diluted (1:10) and plated on Trypticase Soy Agar (TSA). The procedure was performed in triplicates and the plates were incubated for up to 10 hours at $37^{\circ} \mathrm{C}$.

\section{Evaluation of acid resistance in SGF}

After different periods of storage at $4^{\circ} \mathrm{C}$ and $-18^{\circ} \mathrm{C}$, the surviving populations of $\boldsymbol{S}$. Enteritidis were evaluated for resistance to SGF using a protocol adapted from CAMPBELL et al. (2004). First, aliquots of $5 \mathrm{~mL}$ of pork homogenate were transferred to $10 \mathrm{~mL}$ of SGF (pH 1.5) and incubated at $37^{\circ} \mathrm{C}$. The SGF was prepared according to BEUMER et al. (1992) and heated to $37^{\circ} \mathrm{C}$ prior to mixing with homogenate samples. The bacterial count was performed using the drop plate technique on TSA in triplicates.

\section{Statistical analysis}

To evaluate the effect of acid treatment on the survival of cultures at low temperatures, the experiment conducted used a randomized $4 \times 2 \times 5$ factorial design, replicated thrice. This included four treatments (one without acid treatment and three with acid treatment at $\mathrm{pH} 4.0,4.5$, and 5.0), two strains (ATCC 13076 and CCS3) and five periods of storage at $4^{\circ} \mathrm{C}(0,1,3,5$, and 7 days $)$ and $-18^{\circ} \mathrm{C}(0,14,28,56$, and 84 days). Data were analyzed using variance and 
regression analysis. For factors like acid treatment and cultures, the means were compared using the F test and $\mathrm{p}$ values less than 0.05 were considered statistically significant. For factors such as storage period at $4{ }^{\circ} \mathrm{C}$ and time of exposure in SGF, models were based on the significance of regression coefficients, using the t-test, adopting $10 \%$ for probability and magnitude of determination coefficient determination (R2). Statistical analyses were performed using the SAEG software, version 8.0 (UFV, 2000).

\section{RESULTS AND DISCUSSION}

Survival of Salmonella Enteritidis in chilled and frozen pork

Experimental conditions used in this study simulated conditions such as $\mathrm{pH}$ gradient (4.0 to 5.0), cool temperatures $\left(4^{\circ} \mathrm{C}\right)$, frozen storage $\left(-18^{\circ} \mathrm{C}\right)$, and host environment (SFG) that may occur during pork processing. The survival of $\boldsymbol{S}$. Enteritidis CCS3 and ATCC 13076 in chilled pork is shown in figure 1A and $1 \mathrm{~B}$, respectively. Factors such as bacterial strain $(\mathrm{P}<0.05)$ and storage time $(\mathrm{P}<0.001)$ significantly impacted survival of $\boldsymbol{S}$. Enteritidis in refrigerated stored pork, but not after acid treatment $(\mathrm{P}>0.05)$. We observed that the population of the CCS3 strain increased by an average of $0.6 \log$ cycle during storage. However, the population of the ATCC 13076 strain remained almost unchanged (variation of only $0.1 \mathrm{log}$ cycle). This suggested that $\boldsymbol{S}$. Enteritidis ATCC 13076 is more sensitive to low or freezing temperatures than the CCS3 strain. These results; whereas, also confirmed that refrigeration is not sufficient to inhibit $\mathrm{e}$ growth of all $\boldsymbol{S}$. Enteritidis strains in pork. KINSELLA et al. (2007) also observed the survival and increased growth of $\boldsymbol{S}$. enterica serovar Typhimurium DT104 after 72 hours of beef storage at $4^{\circ} \mathrm{C}$.

The survival rate of $\boldsymbol{S}$. Enteritidis stored at $-18^{\circ} \mathrm{C}$ was significantly different between strains $(\mathrm{P}<0.01)$ and between periods of storage $(\mathrm{P}<0.001)$ (Figure 1C and 1D). It was also observed that acid treatment at $\mathrm{pH} 4.0$ to 5.0 , prior to storage, did not affect the survival of $\boldsymbol{S}$. Enteritidis in frozen pork $(\mathrm{P}>0.05)$. There was a decrease in the populations of both strains during the storage period. The mean reduction in viable cells of CCS3 and ATCC 13076 strains was approximately 0.8 and $1.5 \log$ cycles, respectively. $\boldsymbol{S}$. Enteritidis ATCC 13076 had a lower survival rate than $\mathrm{CCS} 3$ strain during storage at freezing temperatures. These observations supported the hypothesis that the ATCC 13076 strain is more sensitive to low temperatures than the CCS3 strain. ESCARTÍN et al. (2000) reported that the decrease in the population of $\boldsymbol{S}$. enterica serovars in naturally

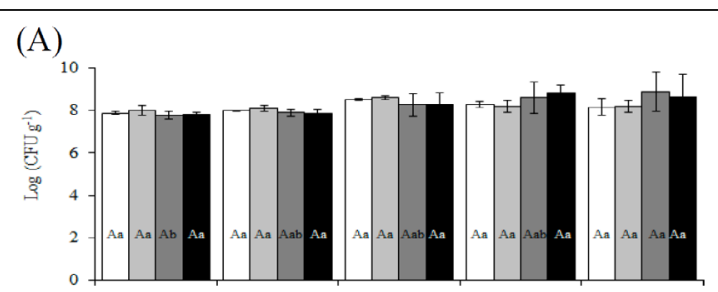

(B)

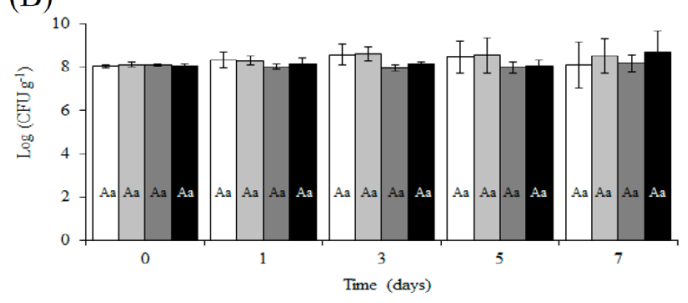

(C)

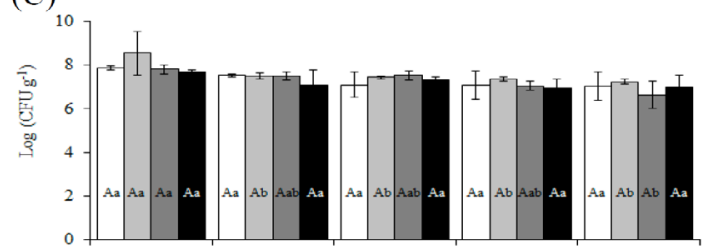

(D)

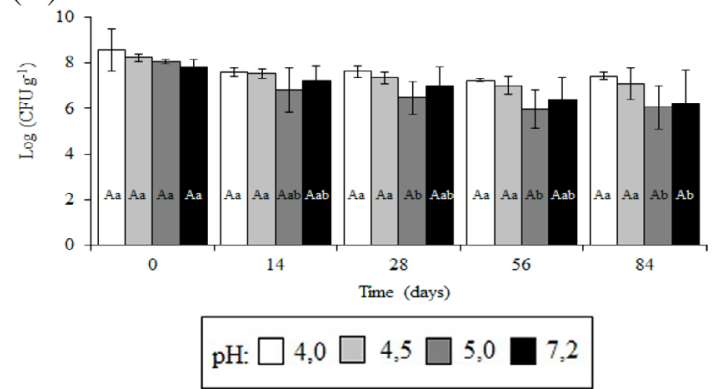

Means denoted as capital letters differ in the conditions of the acid treatments whereas the ones denoted as lowercase letters differ in the evaluation time, according to Tukey test $(\mathrm{P}<0.05)$.

Figure 1 - Logarithm of the number of colony forming units per gram (CFU g $\left.{ }^{-1}\right)$ of Salmonella Enteritidis CCS3 strain (A) and ATCC 13076 strain (B) inoculated in pork meat kept at $4^{\circ} \mathrm{C}$ for up to seven days; and survival of $S$. Enteritidis CCS3 strain (C) and ATCC 13076 strain (D) inoculated in pork meat kept at $-18^{\circ} \mathrm{C}$ for up to 84 days.

contaminated pork, stored at $-15^{\circ} \mathrm{C}$ for 78 weeks, was approximately $3 \log$ cycles.

The differences observed in this study, between the survival of the CCS3 and ATCC 13076 strains at low temperatures could be due to the induction of cold shock proteins that protect cell components, as well as changes in the lipids of the

Ciência Rural, v.46, n.3, mar, 2016. 
cell membrane, DNA supercoiling, and ribosome function (SPECTOR \& KENYON, 2012).

In this research, prior acid treatment of pork did not affect the survival rate of both $\boldsymbol{S}$. Enteritidis CCS3 and ATCC 13076 during storage at refrigeration or freezing temperatures, indicating that there was no cross-resistance. Conversely, cross-resistance was observed for $\boldsymbol{S}$. Enteritidis previously exposed to acidic conditions in culture medium (XU et al., 2008) and for Salmonella Typhimurium in fermented dairy products (SHEN et al., 2007) at low temperatures. This phenomenon investigated food pathogens acquiring resistance to adverse conditions after moderate stress conditions during food processing.

\section{Survival of Salmonella Enteritidis in SGF}

$\boldsymbol{S}$. Enteritidis CCS3 after acid treatment at $\mathrm{pH} 4.0,4.5,5.0$, and 7.2 for $1 \mathrm{~h}$ after challenged at low temperature $\left(4^{\circ} \mathrm{C}\right.$ and $\left.-18^{\circ} \mathrm{C}\right)$ survived in SGF $(\mathrm{pH}$ 1.5) for up to 3 hours (Figure 2), whereas ATCC 13076 strain challenged under the same acidic conditions and low temperature was not detected after $10 \mathrm{~min}$ of exposure in SFG (Table 1). For $\boldsymbol{S}$. Enteritidis CCS3, we observed a significant association $(\mathrm{P}<0.001)$

A)

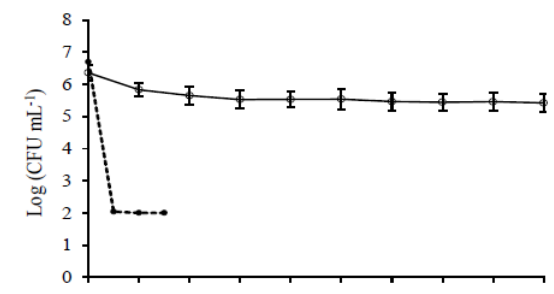

$-18^{\circ} \mathrm{C}$

B)
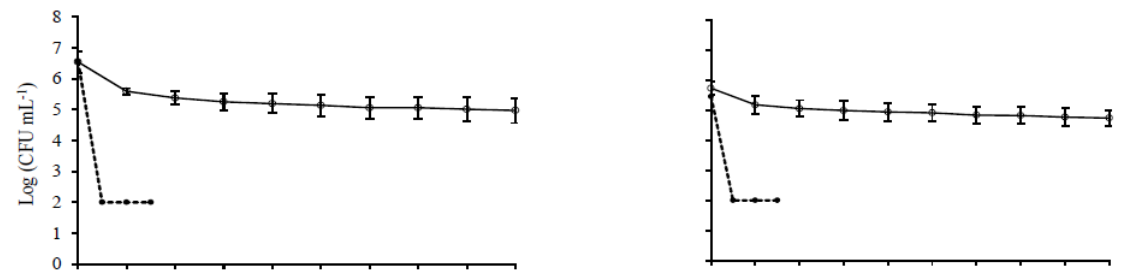

C)
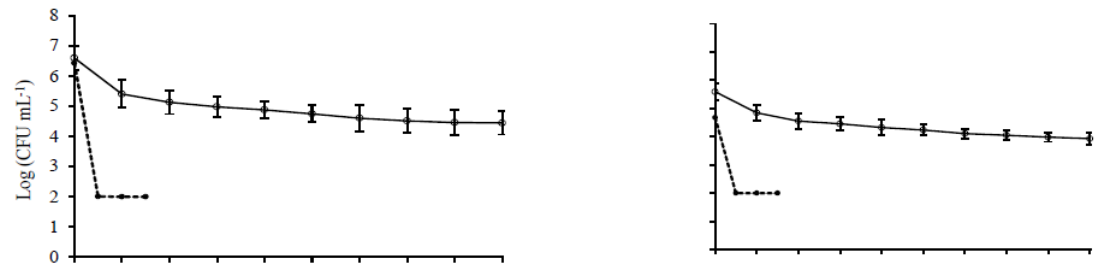

D)
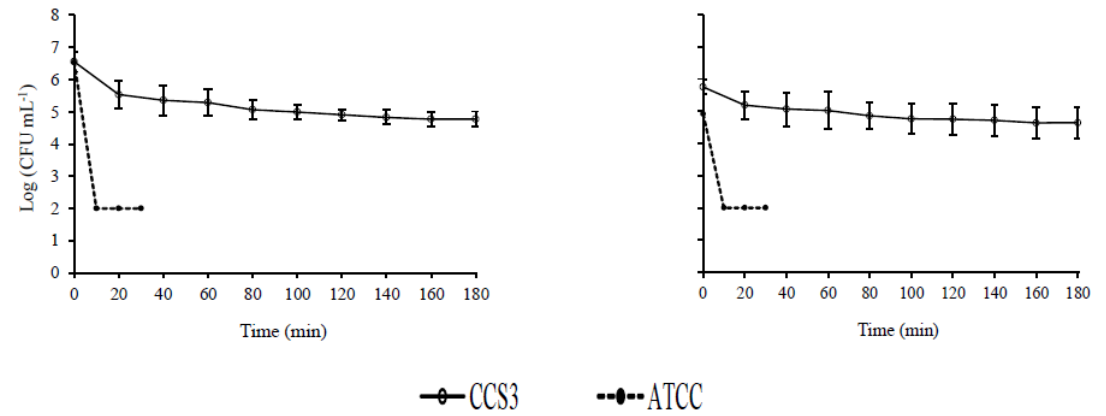

Figure 2 - Survival rate of Salmonella Enteritidis strains, CCS3 and ATCC 13076, in SGF after acid shock treatment at different $\mathrm{pH}$ values for $1 \mathrm{~h}$ and storage at either $4^{\circ} \mathrm{C}$ for 7 days or at $-18^{\circ} \mathrm{C}$ for 84 days. Cells underwent acid treatment at (A) pH 4.0 (B) $\mathrm{pH} 4.5$ (C) 5.0 (D) $\mathrm{pH} 7.2$ (control).

Ciência Rural, v.46, n.3, mar, 2016. 
Table 1 - Survival rate of Salmonella Enteritidis ATCC 13076 (Number of Log CFU mL ${ }^{-1}$ ) in SGF after acid treatment at pH 4.0, 4.5, 5.0, and 7.2 for $1 \mathrm{~h}(\mathrm{P}>0.05)$, and subsequent storage at either $4^{\circ} \mathrm{C}$ for 7 days or at $-18^{\circ} \mathrm{C}$ for 84 days $(\mathrm{P}<0.001)$.

\begin{tabular}{|c|c|c|c|c|}
\hline \multirow{2}{*}{$\mathrm{pH}$ of acid treatment } & \multicolumn{2}{|c|}{--Survival Rate $\left(4^{\circ} \mathrm{C}\right)$------------ } & \multicolumn{2}{|c|}{-----Survival Rate $\left(-18^{\circ} \mathrm{C}\right)$} \\
\hline & $0 \mathrm{~min}$ & $10 \mathrm{~min}$ & $0 \mathrm{~min}$ & $10 \mathrm{~min}$ \\
\hline 4.0 & 6.48 & $=2.0^{*}$ & 5.30 & $=2.0$ \\
\hline 4.5 & 6.38 & $=2.0$ & 4.98 & $=2.0$ \\
\hline 5.0 & 6.55 & $=2.0$ & 4.25 & $=2.0$ \\
\hline 7.2 & 6.70 & $=2.0$ & 4.40 & $=2.0$ \\
\hline
\end{tabular}

${ }^{*}$ Values correspond to the detection limit of the drop plate method.

between exposure time and $\mathrm{pH}$ value of acid treatment and acid resistance in the SGF. Decrease in the population of the CCS3 strain was more substantial during the first 20 minutes of exposure. After this period, the reduction in the number of viable cells was gradual, indicating the development of tolerance in $\boldsymbol{S}$. Enteritidis CCS3 to acidic conditions. Before exposure to SGF, population of $\mathrm{CCS} 3$ strain was approximately 6.5log cycles (Figure 1A and 1B) and $5.8 \log$ cycles after 7 days of refrigeration and 84 days of freezing (Figure 1C and 1D), respectively. After 3 hours of exposure in the SGF, final population of strains stored for 7 days and 84 days reduced to 4.9 and $4.5 \mathrm{log}$ cycles, respectively (Figure 2 ).

The average reduction of the population of $\boldsymbol{S}$. Enteritidis CCS3 was approximately $1.4 \log$ cycle after challenge in SGF. The CCS3 strain previously challenged at $\mathrm{pH} 4.0$ (Figure $2 \mathrm{~A}$ ) showed only a $15 \%$ decrease in the number of log cycles at the end of 180 minutes of exposure to SGF. Therefore, a decrease of approximately $30 \%$ was observed in the CCS3 strain population during the exposure time, after acid treatments at $\mathrm{pH} 4.5$ and 5.0, and in the absence of acid treatment (control) (Figure 2B, 2C, and 2D). This behavior indicated that acid shock at $\mathrm{pH} 4.0$ followed by refrigeration increased the survival rate of CCS3 strain in more acidic environments such as SGF.

The increase in exposure time in SGF significantly reduced $(\mathrm{P}<0.001)$ the population of $\boldsymbol{S}$. Enteritidis ATCC 13076 inoculated in pork stored at refrigeration and freezing temperatures (Table 1). The ATCC 13076 population strain showed a reduction of at least $4 \log$ cycles after 10 minutes of exposure to SGF, indicating high sensitivity to the acidic environment. The survival rate of ATCC 13076 strain did not show significant differences $(\mathrm{P}>0.05)$ between acid treated and control pork stored at refrigeration and freezing temperatures. There was a difference between the survival of $\boldsymbol{S}$. Enteritidis ATCC 13079 and CCS3 in SGF; whereas, the majority of the population of the CCS3 strain remained viable for over three hours of SGF exposure, the population of the ATCC 13076 strain showed a drastic decrease in viability after only 10 minutes of exposure.

In this study, the population of $\boldsymbol{S}$. Enteritidis CCS3 was exposed to acidic conditions ( $\mathrm{pH}$ 4.0) survived better at low temperatures as well as in simulated gastric fluid, which suggested cross-resistance. YUK \& SCHNEIDER (2006) also observed that the adaptation of Salmonella serovars present in refrigerated juices with moderate $\mathrm{pH}$ resulted in increased survival of these cells in SGF.

Furthermore, the results showed that $\boldsymbol{S}$. Enteritidis ATCC 13076 and CCS3 overcame low temperatures in pork after being subjected to acid treatment. However, it is less likely that the ATCC 13076 strain survive the acidic environment created by the gastric juices of the stomach. These results demonstrated that $\boldsymbol{S}$. Enteritidis CCS3 populations exposed to acid solutions such as those used for decontamination of animal carcasses and sanitizing areas in abattoirs developed tolerance to the gastric environment.

\section{CONCLUSION}

Refrigeration of pork did not inhibit the growth of Salmonella Enteritidis CCS3 and ATCC 13076. Although, the ATCC 13076 strain was not detected after 10 minutes, $\boldsymbol{S}$. Enteritidis CCS3 survived for up to 3 hours in SGF. Thus, the $\boldsymbol{S}$. Enteritidis CCS3 strain that was isolated from swine carcass poses a potential risk to the health of consumers due to contamination of undercooked meat as well as cross contamination of ot her food products.

\section{ACKNOWLEDGEMENTS}

We thanks the Fundação de Amparo à Pesquisa do Estado de Minas Gerais (FAPEMIG), the Coordenação de Aperfeiçoamento de Pessoal de Nível Superior (CAPES) and the Conselho Nacional de Desenvolvimento Científico e Tecnológico (CNPq) for providing the financial support required for this study. 


\section{REFERENCES}

ÁLVAREZ-ORDÓÑEZ, A. et al. The acid tolerance response of Salmonella spp: An adaptative strategy to survive in stressful environments prevailing in foods and the host. Food Research International, v.45, p.482-492, 2012. Available from: <http:// www.sciencedirect.com/science/article/pii/S0963996911002195>. Accessed: Apr. 29, 2015. doi: 10.1016/j.foodres.2011.04.002.

BESSA, M.C. et al. Prevalence of Salmonella sp. carrier pigs in slaughterhouses of Rio Grande do Sul, Brazil. Pesquisa Veterinária Brasileira, v.24, p.80-84, 2004. Available from: $<$ http://www.scielo.br/pdf/pvb/v24n2/a06v24n2>. Accessed: Apr. 28, 2013. doi: 10.1590/S0100-736X2004000200006.

BEUMER, R.R. et al. Campylobacter jejuni non-culturable coccoid cells. International Journal of Food Microbiology, v.15, p.153-163, 1992. Available from: <http://mic.sgmjournals. org/content/153/1/291.full.pdf +html>. Accessed: Apr. 29, 2013. doi: $10.1099 /$ mic. $0.28966-0$.

CAMPBELL, J. et al. Effects of salt, acid, and MSG on cold storage survival and subsequent acid tolerance of Escherichia coli $\mathrm{O} 157: \mathrm{H} 7$. Food Microbiology, v.21, p.727-735, 2004. Available from: $<$ http:// www.sciencedirect.com/science/article/pii/S0740002004000267>. Accessed: Apr. 03, 2013. doi: 10.1016/j.fm.2004.02.004.

CDC (CENTERS FOR DISEASE CONTROL AND PREVENTION). Salmonella serotype Enterititids. Online. Available from: <http://www.cdc.gov/nczved/divisions/dfbmd/ diseases/salmonella_enteritidis $>$. Accessed: Jan. 09, 2015.

ESCARTÍN, E.F. et al. Quantitative survival of native Salmonella serovars during storage of frozen raw pork. International Journal of Food Microbiology, v.54, n.19-25, 2000. Available from: <http:// www.sciencedirect.com/science/article/pii/S016816059900149X $>$. Accessed: Jan. 17, 2013. doi: 10.1016/S0168-1605(99)00149-X.

GANTOIS, I. et al. Mechanisms of egg contamination by Salmonella Enteritidis. FEMS Microbiology Reviews, v.33, p.718-738, 2009. Available from: <http://femsre.oxfordjournals. org/content/femsre/33/4/718.full.pdf $>$. Accessed: Jul. 07, 2015. doi: $10.1111 /$ j. 1574-6976.2008.00161.x.

KICH, J.D. et al. Prevalence, distribution, and molecular characterization of Salmonella recovered from swine finishing herds and a slaughter facility in Santa Catarina, Brazil. International Journal of Food Microbiology, v.151, p.307-313, 2011. Available from: <http://www.sciencedirect.com/science/ article/pii/S0168160511005757>. Accessed: Jan. 18, 2013. doi: 10.1016/j.ijfoodmicro.2011.09.024

KINSELLA, K.J. et al. The influence of attachment to beef surfaces on the survival of cells of Salmonella enterica serovar Typhimurium DT104, at different aw values and at low storage temperatures. Food Microbiology, v.24, p.786-793, 2007. Available from: $<$ http:// www.sciencedirect.com/science/article/pii/S0740002007000032>. Accessed: Apr. 21, 2013. doi: 10.1016/j.fm.2006.12.004.

LIMA, E.S.C. et al. Isolation of Salmonella sp. and Staphylococcus aureus at swine slaughtering as subsidy for HACCP, the Hazard Analysis and Critical Control Point system. Pesquisa Veterinária Brasileira, v.24, p.185-190, 2004. Available from: $<$ http://www.scielo.br/scielo.php?script=sci_arttext\&pid=S0100736X2004000400003>. Accessed: Jun. 11, 2012. doi: 10.1590/ S0100-736X2004000400003.

MARIEB, E.N.; HOEHN, K. Human anatomy \& physiology. San Francisco: Benjamin Cummings, 2010. ISBN 0-8053-9591-1.
MORTON, R.D. Aerobic plate count. In DOWNES, F.P.; ITO, K. Compendium of methods for the microbiological examination of foods. 4.ed. Washington: American Public Health Association (APHA), 2001. p.63-67.

MÜLLER, K. et al. Survival and growth of epidemically successful and nonsuccessful Salmonella enterica clones after freezing and dehydration. Journal of Food Protection, v.75, p.456-464, 2012. Available from: <http://www.ncbi.nlm.nih.gov/ pubmed/22410218>. Accessed: May 18, 2013. doi: 10.4315/0362028X.JFP-11-167.

PIPEK, P. et al. Decontamination of pork carcasses by steam and lactic acid. Journal of Food Engineering, v.74, p.224-231, 2006. Available from: $<$ http://www.sciencedirect.com/science/article/pii/ S0260877405001470>. Accessed: Sept. 28, 2014. doi: 10.1016/j. jfoodeng.2005.03.015.

ROWLANDS, R.E. et al. Prevalence of drug resistance and virulence features in Salmonella spp. isolated from foods associated or not with salmonellosis in Brazil. Revista do Instituto de Medicina Tropical de São Paulo, v.56, p.461-467, 2014. Available from: <http://www.scielo.br/scielo.php?pid=S003646652014000600461\&script $=$ sci_arttext $>$. Accessed: Nov. 29, 2014. doi: $10.1590 /$ S0036-46652014000600001.

SHEN, H.W. et al. Acid adaptation affects the viability of Salmonella typhimurium during the lactic fermentation of skim milk and product storage. International Journal of Food Microbiology, v.114, p.380-385, 2007. Available from: <http:// www.sciencedirect.com/science/article/pii/S0168160506005708>. Accessed: Ago. 23, 2014. doi: 10.1016/j.ijfoodmicro.2006.09.033.

SPECTOR, M.P.; KENYON, W.J. Resistance and survival strategies of Salmonella enterica to environmental stresses. Food Research International, v.45, p.455-481, 2012. Available from: <http:// www.sciencedirect.com/science/article/pii/S096399691100439X>. Accessed: Apr. 11, 2013. doi: 10.1016/j.foodres.2011.06.056.

SUN, J. et al. Microbial decontamination of pork carcass and chilled pork by different technological treatments. Food and Fermentation Industries, v.29, p.1-5, 2003. Available from: <http://en.cnki.com. cn/Article en/CJFDTOTAL-SPFX200307000.htm>. Accessed: Apr. 20, 2013. doi:10.1016/j.jfoodeng.2005.03.015.

WINFIELD, M.D.; GROISMAN, E.A. Role of non-host environments in the lifestyles of Salmonella and Escherichia coli. Applied and Environmental Microbiology, v.69, p.3687-3694, 2003. Available from: $<$ http://aem.asm.org/content/69/7/3687.full $>$. Accessed: Apr. 14, 2014. doi: 10.1128/AEM.69.7.3687-3694.2003.

UFV (UNIVERSIDADE FEDERAL DE VICCOSA). SAEG Sistema de análises estatísticas e genéticas. Versão 8.0. Viçosa, MG, 2000. 150p.

XU, H. et al. Cross-protective effect of acid-adapted Salmonella enterica on resistance to -lethal acid and cold stress conditions. Letters in Applied Microbiology, v.47, p.290-297, 2008. Available from: <http://onlinelibrary.wiley.com/>. Accessed: Sept. 19, 2014. doi: 10.1111/j.1472-765X.2008.02429.x.

YUK, H.G.; SCHNEIDER, K.R. Adaptation of Salmonella spp. in juice stored under refrigerated and room temperature enhances acid resistance to simulated gastric fluid. Food Microbiology, v.23, p.694-700, 2006. Available from: <http://www.sciencedirect. com/science/article/pii/S0740002005001449>. Accessed: Apr. 23, 2014. doi: $10.1016 /$ j.fm.2005.12.003.

Ciência Rural, v.46, n.3, mar, 2016. 